\title{
CELL ENVELOPE ALTERATIONS ASSOCIATED WITH SENSITIVITY TO ANTIBACTERIAL AGENTS OF GAMMA-IRRADIATION RESISTANT MUTANTS OF ESCHERICHIA COLI
}

\author{
AKHAND P. SINGH* \\ Department of Microbiology, Macdonald Campus of McGill University, \\ Montreal, P. Quebec, Canada
}

(Received February 5, 1975)

The principle underlying the sensitivity to antibacterial agents of wild type Escherichia coli $\mathrm{P}$ and its $\gamma$-irradiation resistant mutants was studied. These strains were classified as typical rough $(\mathrm{R})$ strains, belonging to classes $\mathrm{Ra}(\mathrm{P}$ and $\gamma)$, and $\mathrm{Rc}(6 \gamma$ and $12 \gamma)$. The galactose-deficient $(\mathrm{Rc})$ strains, $6 \gamma$ and $12 \gamma$, leaked large amounts of alkaline phosphatase, acid phosphatase, 2,3-cyclic phosphodiesterase, and $\beta$-galactosidase into the culture media during active growth, indicating defects in both the outer and inner membranes. Unlike strains $P$ and $\gamma$, strains $6 \gamma$ and $12 \gamma$ were hypersensitive to Actinomycin-D, Bacitracin, Erythromycin, Kanamycin, Novobiocin, penicillin G, Rifamycin, Vancomycin, sodium deoxycholate (DOC), sodium dodecyl sulfate (SDS), ethylenediaminetetraacetic acid (EDTA), lysozyme, and Methylene Blue. Strains P, $6 \gamma$, and $12 \gamma$ showed similar sensitivity to phages $\mathrm{T} 2, \mathrm{~T} 3, \mathrm{~T} 4, \mathrm{~T} 5, \mathrm{~T} 6$, and $\mathrm{T} 7$, and differed from strain $\gamma$, which was sensitive only to phages T2 and T4. Strains P and $6 \gamma$ were sensitive to colicins $E_{1}, E_{2}, E_{3}, G, H$, and $K$, whereas strain $\gamma$ was resistant to colicin $\mathrm{H}$, and $12 \gamma$ was tolerant to colicins $\mathrm{H}$ and $\mathrm{K}$.

On the basis of these observations it is suggested that the leakage of periplasmic enzymes from and the sensitivity of these mutant strains to antibacterial agents are associated with both defects in the cell wall and plasma membrane.

Studies on $\gamma$-irradiation resistant mutants of Escherichia coli have shown that, unlike the less radio-resistant mutant, $\gamma$, and the wild type parent, the more radioresistant mutant strains, $6 \gamma$ and $12 \gamma$, are highly sensitive to lysozyme and Actinomy-

* Present address: Department of Biochemistry, Faculty of Medicine, University of British Columbia, Vancouver, B.C. V6T 1W5, Canada. 
cin-D. In addition, they lack galactose in their lipopolysaccharides, and leak alkaline phosphatase and $\beta$-galactosidase into the culture medium during active growth (1-5). Other differences between the wild type and radio-resistant mutants of $E$. coli include sensitivity to penicillin G (6) and the ability to form 'minicells' (7). It has also been shown that the radio-resistant strains, $6 \gamma$ and $12 \gamma$, are filamentous, and contain a large number of separate mesosomes and cell nuclei $(7,8)$.

This paper describes the results of a comparative study of the sensitivity of wild type and $\gamma$-irradiation resistant mutants of $E$. coli to antibiotics, detergents, dyes, lysozyme, EDTA, phages, and colicins. The chemical composition of the lipopolysaccharides of the wild type and mutant strains was also compared. A preliminary report on some of the characteristics of the $\gamma$-irradiation resistant mutants of $E$. coli has been published (9).

\section{MATERIALS AND METHODS}

Chemicals. Bacitracin, Kanamycin, Erythromycin, Mitomycin-C, and Penicillin G were purchased from Sigma Chemical Co., St. Louis. Rifamycin, OxyTetracycline, and Tetracycline were obtained from Calbiochem, Los Angeles, Calif. Actinomycin-D, Chloramphenicol, Novobiocin, and Vancomycin were gifts of Merck, Sharpe and Dohme of Canada Ltd., Point-Claire, Quebec; Parke, Davis and Co., Ltd., Brockville, Ontario; Upjohn Co., of Canada Ltd., Don Mills, Ontario, and Eli, Lilly and Co., Indianapolis, respectively.

Glucose-6-phosphate dehydrogenase (EC 1.1.1.49), lactate dehydrogenase (EC 1.1.1.27), containing pyruvic kinase (EC 2.7.1.40), phosphoglucomutase (EC 2.7.5.1), uridine 5-diphosphate glucose dehydrogenase (EC 1.1.1.22) type III, lysozyme (EC 3.2.1.17), adenosine 5-triphosphate (ATP), bis-p-nitrophenyl phosphate (bis-PNP), glucose 1-phosphate, glucose 1,6-diphosphate, $\beta$-glycerophosphate, nicotinamide adenine dinucleotide (NAD), and nicotinamide adenine dinucleotide phosphate (NADP), phosphoenol pyruvate, uridine-5-diphosphogalactose (UDP-Gal), and uridine 5-diphosphoglucose (UDPG) were purchased from Sigma Chemical Co., St. Louis. Glucose oxidase (EC 1.1.3.4) and galactose oxidase (EC 1.1.3.9) were obtained from Worthington Biochemical Corp., Freehold, N.J. Isopropyl- $\beta$-D-thiogalactoside (IPTG) and $o$-nitrophenyl- $\beta$-D-galactopyranoside (ONPG) were products of Schuchardt, München. L-Glycero-Dmannoheptose phosphate was a gift of Dr. M. J. Osborn.

Media. Luria broth and agar (10), $\lambda$ broth (11), nutrient broth and agar (Difco), and penassay broth (Difco) were used as enriched media. Chemically defined medium (CDM) was prepared as described by ROBERN and THATCHER (12).

Strains. The bacterial and phage strains used in this study are listed in Table 1.

Sensitivity to antibiotics. The sensitivity of $E$. coli $\mathrm{P}$ and its mutant strains to various antibiotics was measured in penassay broth by the method of TAMAKI et al. (13). 
Table 1. Bacterial and phage strains employed ${ }^{a}$.

\begin{tabular}{|c|c|c|}
\hline Strain & Relevant properties & $\begin{array}{l}\text { Immediate } \\
\text { source }\end{array}$ \\
\hline \multicolumn{3}{|l|}{ E. coli: } \\
\hline $\mathbf{P}$ & Wild type parent & E. I. Erdman \\
\hline$\gamma$ & $\gamma$-radiation resistant mutant & E. I. Erdman \\
\hline $6 \gamma$ & $\mathrm{Leu}^{-}, \mathrm{Met}^{-}, \mathrm{Pro}^{-}$, and resistant to $\gamma$-radiation & E. I. Erdman \\
\hline $12 \gamma$ & Arg $^{-}, \mathrm{Cys}^{-}, \mathrm{His}^{-}, \mathrm{Leu}^{-}, \mathrm{Met}^{-}, \mathrm{Pro}^{-}, \mathrm{Trp}^{-}, \mathrm{Val}^{-}$, & \\
\hline & $\mathrm{Lac}^{-}, \mathrm{Gal}^{-}, \mathrm{Uracil}^{-}$, resistant to $\gamma$-radiation & E. I. Erdman \\
\hline CA38 (col E3/I) & Produces colicin E3/I & J. Smarda \\
\hline CA42 (col E2) & Produces colicin E2 & J. Smarda \\
\hline CA46 (col G) & Produces colicin $\mathrm{G}$ & J. Smarda \\
\hline CA58 ( $\mathrm{col} \mathrm{H})$ & Produces colicin $\mathrm{H}$ & J. Smarda \\
\hline $\mathrm{K} 235$ (col K) & Produces colicin $\mathbf{K}$ & B. D. Sanwal \\
\hline Y20 (col E) & Produces colicin E1 & B. D. Sanwal \\
\hline $\mathrm{B} 2156$ & Host strain for phages $\mathrm{C} 21, \mathrm{~T} 3, \mathrm{~T} 5 \& \mathrm{~T} 7$ & G. Schmidt \\
\hline \multicolumn{3}{|l|}{ S. typhimurium: } \\
\hline RC903 (col E1) & Produces colicin E1 & S. Silver \\
\hline RC906 (col E2) & Produces colicin E2 & S. Silver \\
\hline SL869 & Host strain for phage P221 & G. Schmidt \\
\hline SL1546 & Host strain for phage P22 & G. Schmidt \\
\hline \multicolumn{3}{|l|}{ S. paratyphi: } \\
\hline B309 & Host of phage FO & G. Schmidt \\
\hline Kroger I/2 & Host of phages $\mathrm{Br} 2, \mathrm{Br} 10, \mathrm{Br} 60$ & G. Schmidt \\
\hline $\mathrm{BR}$ & Host of phage Ffm & G. Schmidt \\
\hline A $59 / 28$ & Host of phage 6SR & G. Schmidt \\
\hline \multicolumn{3}{|l|}{ Bacteriophage: } \\
\hline P22 & $\begin{array}{l}\text { LPS specific phage, attacks only } \\
\text { smooth strain }\end{array}$ & G. Schmidt \\
\hline FO & Lyses both smooth and rough strains & G. Schmidt \\
\hline \multicolumn{3}{|l|}{$\mathrm{P} 221, \mathrm{Ffm}, 6 \mathrm{SR}, \mathrm{Br} 2$, } \\
\hline $\mathrm{Br} 10, \mathrm{C} 21$ & Lyses rough strains only & G. Schmidt \\
\hline $\mathrm{T} 2, \mathrm{~T} 3, \mathrm{~T} 4, \mathrm{~T} 5, \mathrm{~T} 7$ & Coli phage & G. Schmidt \\
\hline BF23 & Same receptor as E-group colicins & P. Fredericq \\
\hline T6 & Same receptor as colicin $\mathrm{K}$ & P. Fredericq \\
\hline
\end{tabular}

$a$ The definition of the genetic symbols follow TAYLOR and TROTTER (66). For full description of phages, see LINDBERG (28).

Sensitivity to detergents and dyes. The effect of sodium deoxycholate (DOC), sodium dodecyl sulfate (SDS), and EDTA on the growth of E. coli $\mathrm{P}, \gamma, 6 \gamma$, and $12 \gamma$ was determined by the procedures described by NAGEL DE ZWAIG and LURIA (11). Sensitivity to dyes was estimated by determining the colony-forming ability of the bacteria on nutrient agar plates containing different concentrations of the various dyes.

Effect of detergents, lysozyme, and EDTA on cell lysis. The sensitivity of wild type $\mathrm{P}$ and mutant strains to DOC, SDS, lysozyme alone and in combination with EDTA was measured by determining the lysis of a washed cell suspension 
in the presence of lytic agents. The reaction mixture in a total volume of $3 \mathrm{ml}$

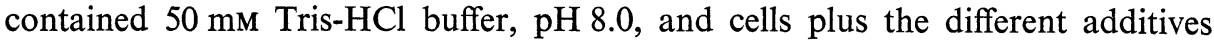
at the concentrations indicated. The absorbance change was recorded at $600 \mathrm{~nm}$ with a Coleman 124 recording spectrophotometer. The lysis of cells in the presence of Tris buffer was used as the control.

Phage and colicins. Sensitivity to phages and colicins was determined by the drop on lawn method $(14,15)$. About $10^{8}$ cells of the test strains were spread on nutrient agar (NA) plates and the plates were dried for 10 to $20 \mathrm{~min}$ at $37^{\circ}$. One drop of phage suspension $\left(10^{8} \mathrm{pfu} / \mathrm{ml}\right)$ or colicin solutions $\left(10^{11}\right.$ to $10^{12} \mathrm{killing}$ particles $/ \mathrm{ml}$ ) was spotted on dried plates which were then incubated at $37^{\circ}$. Results were recorded after 5 and $12 \mathrm{hr}$.

Binding of colicin to intact cells. The binding of colicin $\mathrm{K}$ and $\mathrm{H}$ to intact cells of $\mathrm{P}, \gamma$, and $12 \gamma$ strains was estimated by the method of SABET and SCHNAITMAN (16).

Isolation and chemical analysis of lipopolysaccharide. Lipopolysaccharide (LPS) was extracted from cells grown on nutrient broth containing $0.3 \%$ yeast extract (NBYE) by the phenol-water method described by WESTPHAL and JANN (17). Sugars were estimated by colorimetric methods or by paper chromatography as described previously $(1,4)$. Glucose and galactose were determined by glucose and galactose oxidase, respectively; 1-glycero-D-mannoheptose and 2-keto-3deoxyoctonate (KDO) were measured by the method of OsBORn (18). Phosphorus was estimated by the procedure of CHEN et al. (19).

Enzyme assays. Galactokinase (EC 2.7.1.6), galactose-1-phosphate uridyl transferase, uridine diphosphogalactose-4-epimerase, 2,3-cyclic phosphodiesterase, acid phosphatase, alkaline phosphatase, and $\beta$-galactosidase were measured according to published procedures (20-26).

\section{RESULTS}

\section{Cultural characteristics}

The colony morphology and agglutinability of strains $\mathrm{P}, \gamma, 6 \gamma$, and $12 \gamma$ of $E$. coli in $0.3 \%$ auramine, $0.2 \%$ acriflavine, and $0.85 \% \mathrm{NaCl}$ are shown in Table 2 .

Table 2. Colony morphology and agglutination characteristics of wild type Escherichia coli $\mathrm{P}$ and its $\gamma$-irradiation resistant mutant strains.

\begin{tabular}{ccccc}
\hline \multirow{2}{*}{$\begin{array}{c}\text { E. coli } \\
\text { strains }\end{array}$} & $\begin{array}{c}\text { Colony morphology }^{a} \\
\text { on NAYE plate }\end{array}$ & Auramine & Acriflavine & $\mathrm{NaCl}$ \\
\cline { 3 - 5 } & $\mathrm{P}$ & + & + & - \\
$\gamma$ & $\mathrm{SR}$ & - & + & + \\
$6 \gamma$ & $\mathrm{R}$ & + & + & + \\
$12 \gamma$ & $\mathrm{R}$ & + & + & + \\
\hline
\end{tabular}

a $\mathrm{R}=$ rough; $\mathrm{SR}=$ smooth and rough.

$b \quad+=$ agglutinated; $\quad-=$ not agglutinated.

c Microscopic slide agglutination test was used to determine the auto-agglutination ability of $E$. coli $\mathrm{P}$ and its mutant strains in auramine, acriflavine and $\mathrm{NaCl}$. 
The colony morphology of strains $\mathrm{P}, 6 \gamma$, and $12 \gamma$ on nutrient agar plate indicated that these strains were rough $(\mathrm{R})$ whereas the $\gamma$ strain produced smooth $(\mathrm{S})$ colonies. Strains $6 \gamma$ and $12 \gamma$ gave positive agglutination tests in auramine, acriflavine, and $\mathrm{NaCl}$, whereas strains $\mathrm{P}$ and $\gamma$ did not agglutinate in $\mathrm{NaCl}$ and auramine, respectively (Table 2 and Ref. 1 ). Auto-agglutination ability of E. coli $\mathrm{P}$ and its mutant strains in auramine, acriflavine and $\mathrm{NaCl}$ was determined by microscopic slide agglutination test (see legend to Table 2). The results reported on auramine agglutination were also confirmed in Dr. Luderitz's laboratory (Dr. G. Schmidt, personal communication, 1972).

\section{Pathogenicity}

The roughness of the $\mathrm{P}, 6 \gamma$, and $12 \gamma$ strains was further confirmed by pathogenicity trials in mice. About $10^{9}$ viable cells $/ \mathrm{ml}$ of $E$. coli $\mathrm{P}, \gamma, 6 \gamma$, and $12 \gamma$ were injected intraperitoneally into mice. Under these conditions no deaths occurred during the 15-day observation period.

\section{Sensitivity to LPS-specific phages}

The smooth (S) and rough (R) strains of E. coli and Salmonella typhimurium have also been characterized by their sensitivity to a series of $S$ and $R$ specific phages, and a correlation has been obtained between phage sensitivity pattern and the polysaccharide composition of their LPS (27-29). The sensitivity to different LPS specific phages of E. coli $\mathrm{P}$ and its $\gamma$-irradiation resistant mutants was therefore tested. Strains $6 \gamma$ and $12 \gamma$ were sensitive to R-specific phages P221, Ffm, $\mathrm{Br} 2, \mathrm{Br} 10, \mathrm{Br} 60$, and $\mathrm{C} 21$ (Table 3 ). The phage sensitivity pattern of these strains resembled that of $S$. typhimurium mutants with no functional UDPGal-4-epimerase (28), but differed from that of the $\gamma$-irradiation resistant mutants of Salmonella spp. (30-33). Strain $\mathrm{P}$ gave a phage sensitivity pattern similar to those of $6 \gamma$ and $12 \gamma$, with the exception that it was resistant to phages Ffm and Br60. Strain $\gamma$ was resistant to all phages except the R-specific phage, Ffm. These results were also corroborated by Dr. G. Schmidt (personal communication, 1972).

Table 3. Phage sensitivity pattern of wild type and radiation resistant mutants of $E$. coli.

\begin{tabular}{|c|c|c|c|c|c|c|c|c|c|}
\hline \multirow{2}{*}{$\begin{array}{l}\text { E. coli } \\
\text { strains }\end{array}$} & \multicolumn{9}{|c|}{ Sensitivity to phage types ${ }^{a}$} \\
\hline & $\underset{\mathrm{P} 22}{\mathrm{~S}}$ & $\begin{array}{l}\text { SR } \\
\text { FO }\end{array}$ & P221 & $6 \mathrm{SR}$ & $\underset{\mathrm{Ffm}}{\mathrm{R}}$ & $\mathrm{Br} 2$ & Br10 & Br60 & $\mathrm{C} 21$ \\
\hline $\mathbf{P}$ & - & - & + & - & - & + & + & - & + \\
\hline$\gamma$ & - & - & - & - & + & - & - & - & - \\
\hline $6 \gamma$ & - & - & + & - & + & + & + & + & + \\
\hline $12 \gamma$ & - & - & + & - & + & + & + & + & + \\
\hline
\end{tabular}

$a \quad+=$ lysis; $-=$ no lysis; $\mathrm{S}=$ smooth specific; $\mathrm{SR}=$ semirough; $\mathrm{R}=$ rough specific. 
Table 4. Sensitivity of wild type and radiation-resistant mutants of $E$. coli to various T phages.

\begin{tabular}{cccccccc}
\hline \multirow{2}{*}{$\begin{array}{c}\text { E. coli } \\
\text { strains }\end{array}$} & T1 & T2 & T3 & T4 & T5 & T6 & T7 \\
\cline { 2 - 8 } & P.T. & + & + & + & + & + & + \\
$\gamma$ & N.T. & \pm & - & + & - & - & - \\
$6 \gamma$ & N.T. & + & + & + & + & + & + \\
$12 \gamma$ & N.T. & + & + & + & + & + & + \\
\hline
\end{tabular}
tested.

\section{Sensitivity to $T$ phages}

It has been reported $(28,34,35)$ that the phages, $\mathrm{T} 3, \mathrm{~T} 4$, and $\mathrm{T} 7$, are rough specific and have their receptors in the LPS. Strains $\mathrm{P}, 6 \gamma$, and $12 \gamma$ were sensitive to all $\mathrm{T}$ phages tested (Table 4), whereas strain $\gamma$ was resistant to phages $\mathrm{T} 3, \mathrm{~T} 5$, $\mathrm{T} 6$, and $\mathrm{T} 7$ but was sensitive to phages $\mathrm{T} 2$ and $\mathrm{T} 4$ at very high multiplicity $\left(10^{10}\right.$ $\mathrm{pfu} / \mathrm{ml})$.

Table 5. Sensitivity of wild type and radiation-resistant mutants of $E$. coli to various colicins and phages $\mathrm{BF} 23$ and T6.

\begin{tabular}{|c|c|c|c|c|c|c|c|c|}
\hline \multirow{2}{*}{$\begin{array}{l}\text { E. coli } \\
\text { strains }\end{array}$} & \multicolumn{6}{|c|}{ Colicin sensitivity $^{a}$} & \multicolumn{2}{|c|}{ Phage sensitivity ${ }^{a}$} \\
\hline & $E_{1}$ & $\mathrm{E}_{2}$ & $E_{3}$ & G & $\mathrm{H}$ & $\mathrm{K}$ & $\mathrm{BF} 23$ & T6 \\
\hline $\mathbf{P}$ & + & + & + & + & + & + & - & + \\
\hline$\gamma$ & + & + & + & + & - & + & - & - \\
\hline $6 r$ & + & + & + & + & + & + & + & + \\
\hline $12 \gamma$ & + & + & + & + & - & - & - & + \\
\hline
\end{tabular}

\section{Sensitivity to colicin}

The colicins of the E-group share a common receptor with phage BF23, and colicin $\mathrm{K}$ with that of phage T6 $(11,36)$. The sensitivity of $E$. coli strains $\mathrm{P}, \gamma$, $6 \gamma$ and $12 \gamma$ to various colicins and phages, T6 and BF23, is shown in Table 5. Strains $P, \gamma, 6 \gamma$, and $12 \gamma$ were sensitive to colicins $E_{1}$ to $E_{3}$ and $G$, but they differed in their response to colicins $\mathrm{H}$ and $\mathrm{K}$, and phages BF23 and T6. The binding of colicin $\mathrm{H}$ and $\mathrm{K}$ to whole cells of strains $\gamma$ and $12 \gamma$, respectively, indicated that the strain $\gamma$ was resistant (receptor minus) to colicin $\mathrm{H}$ while $12 \gamma$ was tolerant (contains receptor but lacks specific transmission mechanism) to colicin $\mathrm{K}$. These results also suggest that phage $\mathrm{BF} 23$ do not share a common receptor with colicin $\mathrm{E}$ and phage T6 with that of colicin $\mathrm{K}(11,36)$.

\section{Chemical composition of LPS}

The roughness of strains $P, \gamma, 6 \gamma$, and $12 \gamma$ was also confirmed by chemical analysis of their LPS (Table 6). The LPS of all the strains lacked mannose and 
Table 6. Polysaccharide and phosphate composition of the lipopolysaccharides of $E$. coli $\mathrm{P}$ and its $\gamma$-irradiation resistant mutant strains.

\begin{tabular}{ccccccc}
\hline \multirow{2}{*}{$\begin{array}{c}E . \text { coli } \\
\text { strains }\end{array}$} & \multicolumn{5}{c}{ Composition of lipopolysaccharide (nmol/mg of LPS) } \\
\cline { 2 - 7 } & Rhamnose & Glucose & Galactose & Heptose & KDO & PO $_{4}$ \\
\hline $\mathrm{P}$ & 0 & 493 & 205 & 493 & 205 & 78 \\
$\gamma$ & 0 & 513 & 206 & 493 & 200 & 40 \\
$6 \gamma$ & 0 & 376 & 0 & 633 & 195 & 64 \\
$12 \gamma$ & 0 & 707 & 0 & 598 & 184 & 39 \\
\hline
\end{tabular}

Abbreviations: $\mathrm{KDO}=2$ keto-3-deoxyoctonate; $\mathrm{PO}_{4}=$ phosphate.

Table 7. Specific activities of various galactose operon enzymes in cell-free extracts prepared from wild type

$E$. coli $\mathrm{P}$ and its $\gamma$-irradiation resistant mutants.

\begin{tabular}{crcc}
\hline \multirow{2}{*}{$\begin{array}{c}E . ~ c o l i \\
\text { strains }\end{array}$} & \multicolumn{3}{c}{ Galactose operon enzymes specific activity $(\mu \mathrm{mol} / \mathrm{mg} \text { protein } / \mathrm{hr})^{a}$} \\
\cline { 2 - 4 } & Kinase & Transferase & Epimerase \\
\hline P & 60.7 & 40 & 34 \\
$\gamma$ & 58.2 & 41 & 32.5 \\
$6 \gamma$ & 44.5 & 36.2 & 1.1 \\
$12 \gamma$ & 0.6 & 39.8 & 0.4 \\
\hline
\end{tabular}

a Specific activities were corrected for the uninduced basal level of the various enzymes. Enzymes were induced by growing the bacteria at $37^{\circ} \mathrm{C}$ in peptone broth containing $10^{-2}$ M D-galactose.

rhamnose, indicating that these strains lack the $o$-antigenic side chain (29). This conclusion is consistent with the phage-sensitivity pattern shown in Table 3 . The amount of heptose and KDO was approximately the same in all the strains, but the content of phosphate was 40 to $50 \%$ less in the LPS of $\gamma$ and $12 \gamma$ strains (Table 6). As reported previously (4), no galactose was found in the LPS of the $6 \gamma$ and $12 \gamma$ strains, and the content of glucose was slightly higher in $12 \gamma$ LPS (Table 6).

The absence of galactose in the LPS of strains $6 \gamma$ and $12 \gamma$ was due to the lack of UDPGal-4-epimerase (Table 7). Thus these strains are unable to synthesize LPS-galactose in the absence of exogenous galactose. In addition, strain $12 \gamma$ also lacked galactokinase (Table 7).

\section{Effect of galactose on growth}

The addition of galactose to either a complex or a chemically defined medium containing glycerol as the carbon source caused severe inhibition of the growth of the $12 \gamma$ strain (Fig. 1 and Ref. 37-40). In contrast, the growth of the $6 \gamma$ strain was not affected by galactose (Fig. 1). In the presence of an osmotic stabilizer, galactose inhibited the growth of strains $6 \gamma$ and $12 \gamma$, and also caused the formation of spheroplasts from the growing cells of these strains. 


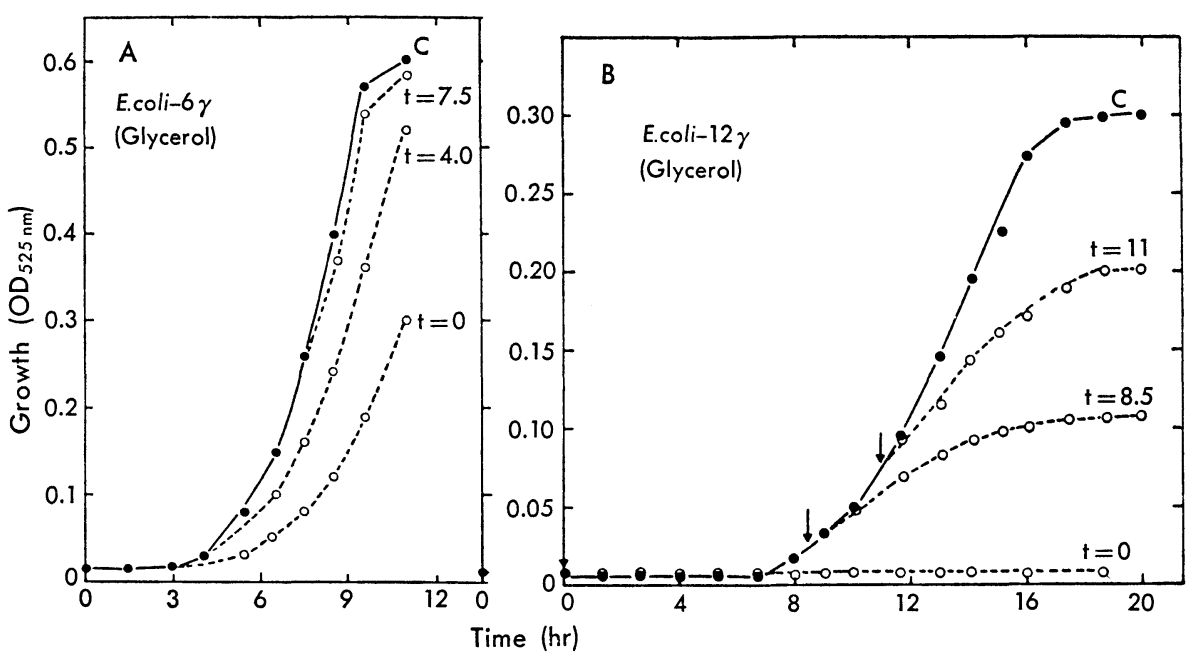

Fig. 1. Effect of galactose $(0.1 \%)$ on the growth of E. coli $6 \gamma$ and $12 \gamma$ in chemically defined medium (12) containing $0.5 \%$ glycerol as a carbon source.

Symbols: $t=$ time of addition of galactose, - $-\mathrm{C}$ (control, without galactose), ---O-- + galactose. Under these conditions, galactose had no effect either on the growth of wild type $E$. coli $\mathrm{P}$ or less radiation resistant mutant strain.

Table 8. Concentration of various antibacterial agents required to inhibit $50 \%$ growth $\left(\mathrm{IG}_{50}\right)$ of $E$. coli $\mathrm{P}$ and its $\gamma$-irradiation resistant mutants at $37^{\circ} \mathrm{C}$ under shaking conditions.

\begin{tabular}{|c|c|c|c|c|}
\hline \multirow{2}{*}{$\begin{array}{l}\text { Antibacterial } \\
\text { agents }\end{array}$} & \multicolumn{4}{|c|}{ E. coli strains } \\
\hline & $\mathbf{P}$ & $\gamma$ & $6 \gamma$ & $12 \gamma$ \\
\hline & \multicolumn{4}{|c|}{$\mathrm{IG}_{50}(\mu \mathrm{g} / \mathrm{ml})$} \\
\hline Bacitracin & 680 & 550 & 410 & 80 \\
\hline Penicillin G & 41.5 & 8 & 4 & 1.5 \\
\hline Novobiocin & 46 & 12.5 & 10 & 10 \\
\hline Vancomycin & 71 & 33 & 25.5 & 6 \\
\hline EDTA & $>2000$ & 750 & 370 & 120 \\
\hline Actinomycin D & 70 & 47 & 36 & 3 \\
\hline Rifamycin & 97.5 & 76.5 & 41.5 & 5 \\
\hline Erythromycin & 14.5 & 15.6 & 3 & 0.5 \\
\hline Kanamycin & 2.7 & 2.8 & 1.2 & 0.4 \\
\hline Tetracycline & 0.1 & 0.1 & 0.05 & 0.4 \\
\hline Oxytetracycline & 0.14 & 0.18 & 0.09 & 0.3 \\
\hline Methylene Blue & $>100$ & $>100$ & 25 & 5 \\
\hline Deoxycholate & $>5000$ & $>5000$ & $>5000$ & 1500 \\
\hline Sodium dodecyl sulfate & $>4000$ & $>4000$ & 1500 & 150 \\
\hline
\end{tabular}

a Antibacterial agents are grouped according to their site of action. The first 5 agents act either at the cell wall or outside the plasma membrane, and the remaining agents act either on the plasma membrane or in the cytoplasm (65). 

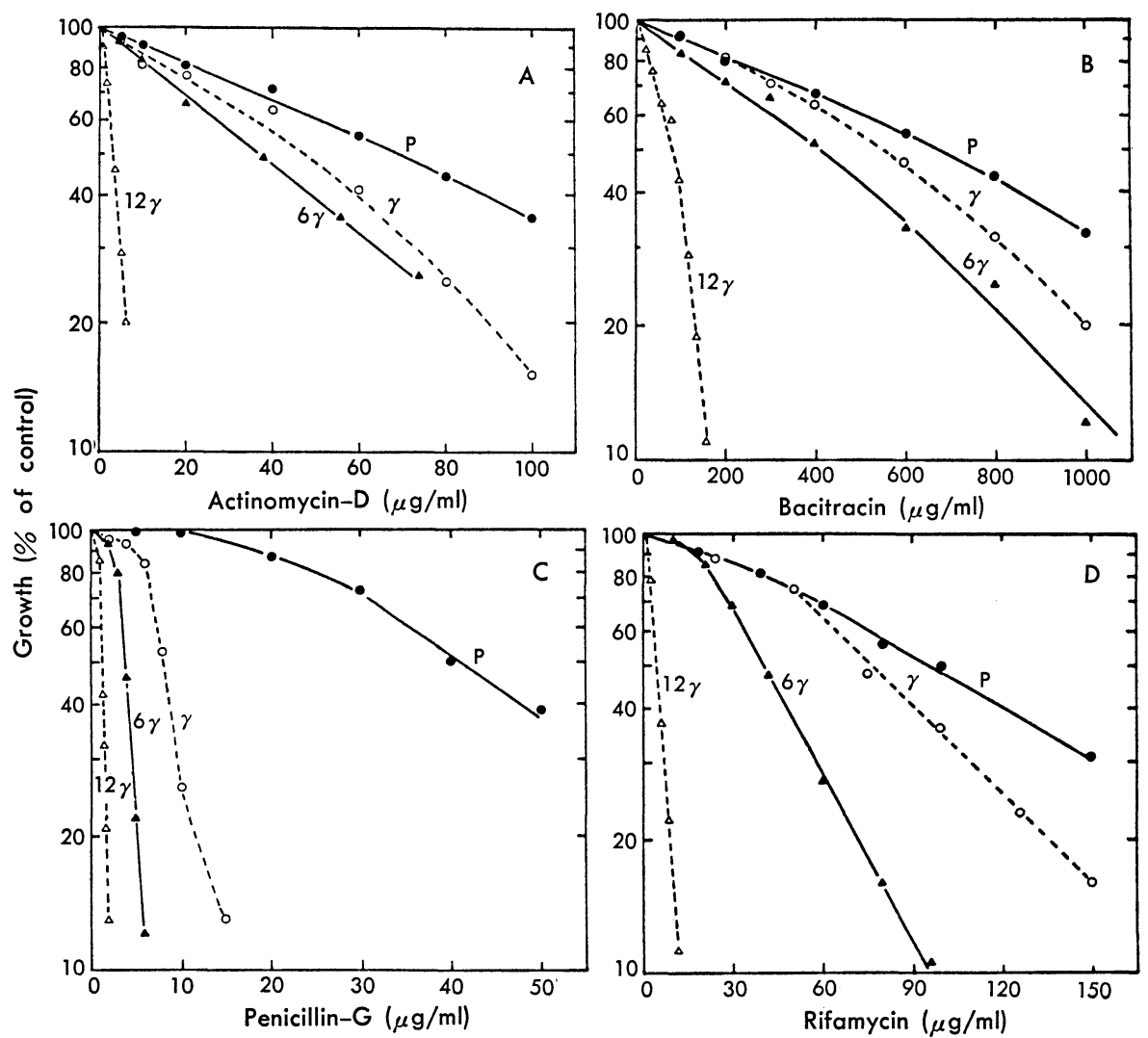

Fig. 2. Effect of different concentrations of Actinomycin D, Bacitracin, Erythromycin, Kanamycin, Novobiocin, penicillin G, Rifamycin, Vancomycin, tetracycline, and oxytetracycline on the growth of wild type $E$. coli $\mathrm{P}$ and its $\gamma$-irradiation resistant mutant strains, $\gamma, 6 \gamma$, and $12 \gamma$.

Cells were grown at $37^{\circ}$ in Penassay broth (Difco) under shaking conditions, for $4 \mathrm{hr}(\mathrm{P}, \gamma), 6 \mathrm{hr}(6 \gamma)$, and $10 \mathrm{hr}(12 \gamma)$. Cell growth was estimated from the absorption at $660 \mathrm{~nm}$. Under these growth conditions, the mean generation time was $30 \mathrm{~min}$ $(\mathrm{P}, \gamma), 45 \min (6 \gamma)$, and $96 \min (12 \gamma)$.

\section{Effect of antibacterial agents on wild type and mutant strains}

(a) Antibiotics. It has been observed that smooth (S) strains of both E. coli and Salmonella species are more resistant to the lethal action of certain antibiotics than the rough $(\mathrm{R})$ strains; and a correlation between sensitivity to antibiotics and LPS structure has been reported (41-48). The wild type E. coli $\mathrm{P}$ and its $\gamma$-irradiation resistant mutants were therefore tested for sensitivity to various antibiotics, and the results are summarized in Table 8 and Fig. 2. In contrast to the $\gamma$-irradiation resistant mutants of Salmonella species (30-33), the $\gamma$-irradiation resistant mutant strain $12 \gamma$ was most sensitive to Actinomycin-D, Bacitracin, penicillin $G$, 

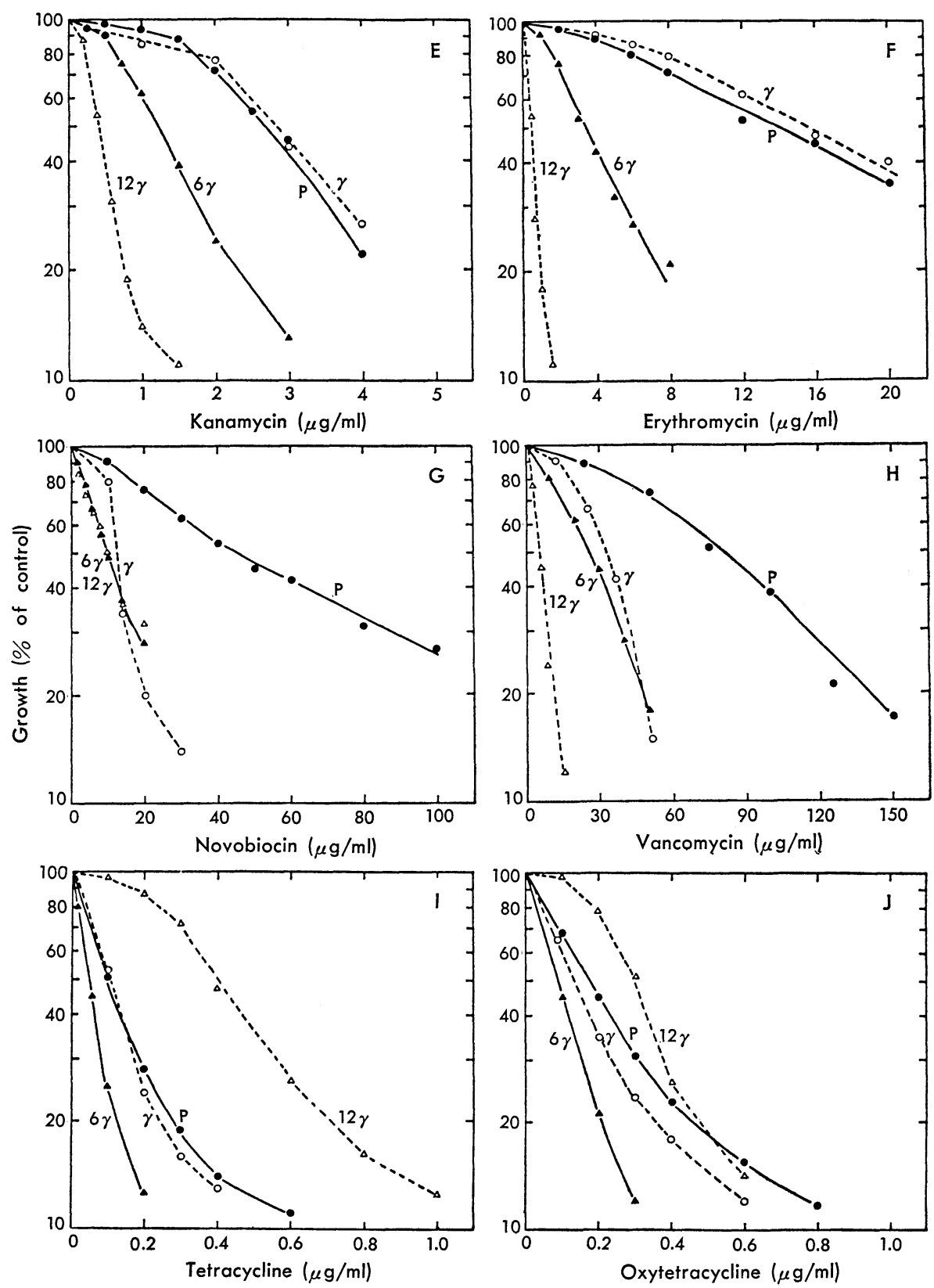

Fig. 2 (continued).

Rifamycin, and Vancomycin. Strains $6 \gamma, \gamma$, and P showed progressively less sensitivity to these antibiotics (Fig. 2 and Table 8). In general, the reduction in growth of $12 \gamma$ was directly proportional to the concentration of the antibiotics (Fig. 2). 
Strain $12 \gamma$ was also found to be most sensitive to Kanamycin and Erythromycin, whereas strains $6 \gamma, \mathrm{P}$, and $\gamma$ displayed successively decreasing sensitivity to these antibiotics (Fig. 2). Strain $P$ was less sensitive to Novobiocin than strains $\gamma, 6 \gamma$, and $12 \gamma$ which exhibited a similar degree of sensitivity (Fig. 2). Strain $12 \gamma$ was found to be most resistant to tetracycline and oxytetracycline, strain $6 \gamma$ was most sensitive, and intermediate values were obtained for strains $P$ and $\gamma$ (Fig. 2).

(b) Dyes. In contrast to the LPS-defective mutants of Salmonella spp. (41$43,45,46)$, the wild type $E$. coli $\mathrm{P}$ and its $\gamma$-irradiation resistant mutants were all insensitive to acriflavine, Acridine Orange, Crystal Violet, and Melachite Green but differed in their reaction to Methylene Blue (Fig. 3). The increased sensitivity of $12 \gamma$ to Methylene Blue was due to the greater uptake and binding of the dye

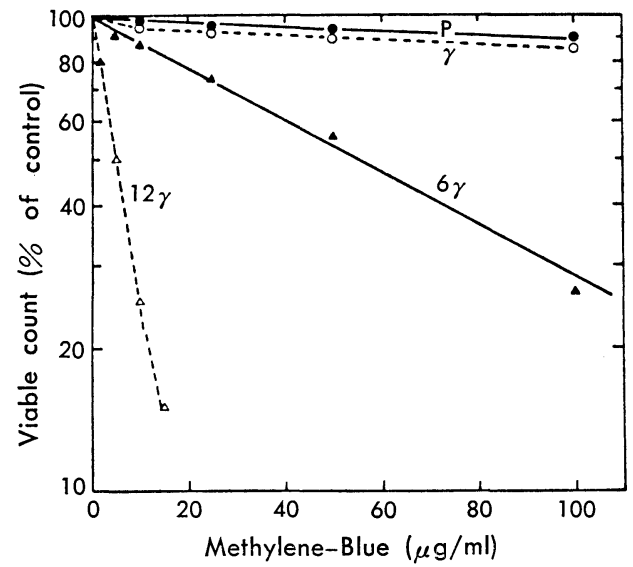

Fig. 3. Effect of different concentrations of Methylene Blue on the colony-forming ability of $E$. coli $\mathrm{P}$ and its mutant strains, $\gamma, 6 \gamma$, and $12 \gamma$.

Serially diluted mid log phase cells $(0.2 \mathrm{ml})$ of various test strains were plated in triplicate on the surface of various nutrient agar plates containing different concentrations of the dye. Plates without dye were used as controls. The colonies were counted after 24 or $48 \mathrm{hr}(12 \gamma)$ of incubation at $37^{\circ}$.

Table 9. Uptake and/or binding of Methylene Blue by cells of wild type $E$. coli $\mathrm{P}$ and its mutant strains.

\begin{tabular}{cc}
\hline $\begin{array}{c}E . \text { coli } \\
\text { strains }\end{array}$ & $\begin{array}{c}\text { Methylene Blue bound } \\
\text { (\% of control) }\end{array}$ \\
\hline $\mathrm{P}$ & 1.8 \\
$\gamma$ & 1.8 \\
$6 \gamma$ & 5.0 \\
$12 \gamma$ & 20.0 \\
\hline
\end{tabular}

a Bacteria $(0.5 \mathrm{mg}$ protein $/ \mathrm{ml})$ were incubated for $15 \mathrm{~min}$ at $37^{\circ}$ in chemically defined medium (12) containing $20 \mu \mathrm{g} / \mathrm{ml}$ Methylene Blue (100\% control). Samples were removed at time zero (zero control) and, after $15 \mathrm{~min}$, cells were removed by centrifugation and the amount of dye remaining in the supernatant was measured spectrophotometrically at $665 \mathrm{~nm}$. 
to the cell surface of this strain (Table 9).

(c) Effect of detergents. It has been shown that colicin-tolerant and antibiotic-sensitive mutants of $E$. coli are hypersensitive to the detergents, DOC and SDS $(11,49-52)$. Strain $12 \gamma$ was most sensitive to DOC and SDS, and strain $\gamma$ was least sensitive, while strain $6 \gamma$ showed an intermediate level of sensitivity to these detergents (Table 8 and Fig. 4). The wild type strain $P$ was not affected by either DOC or SDS.
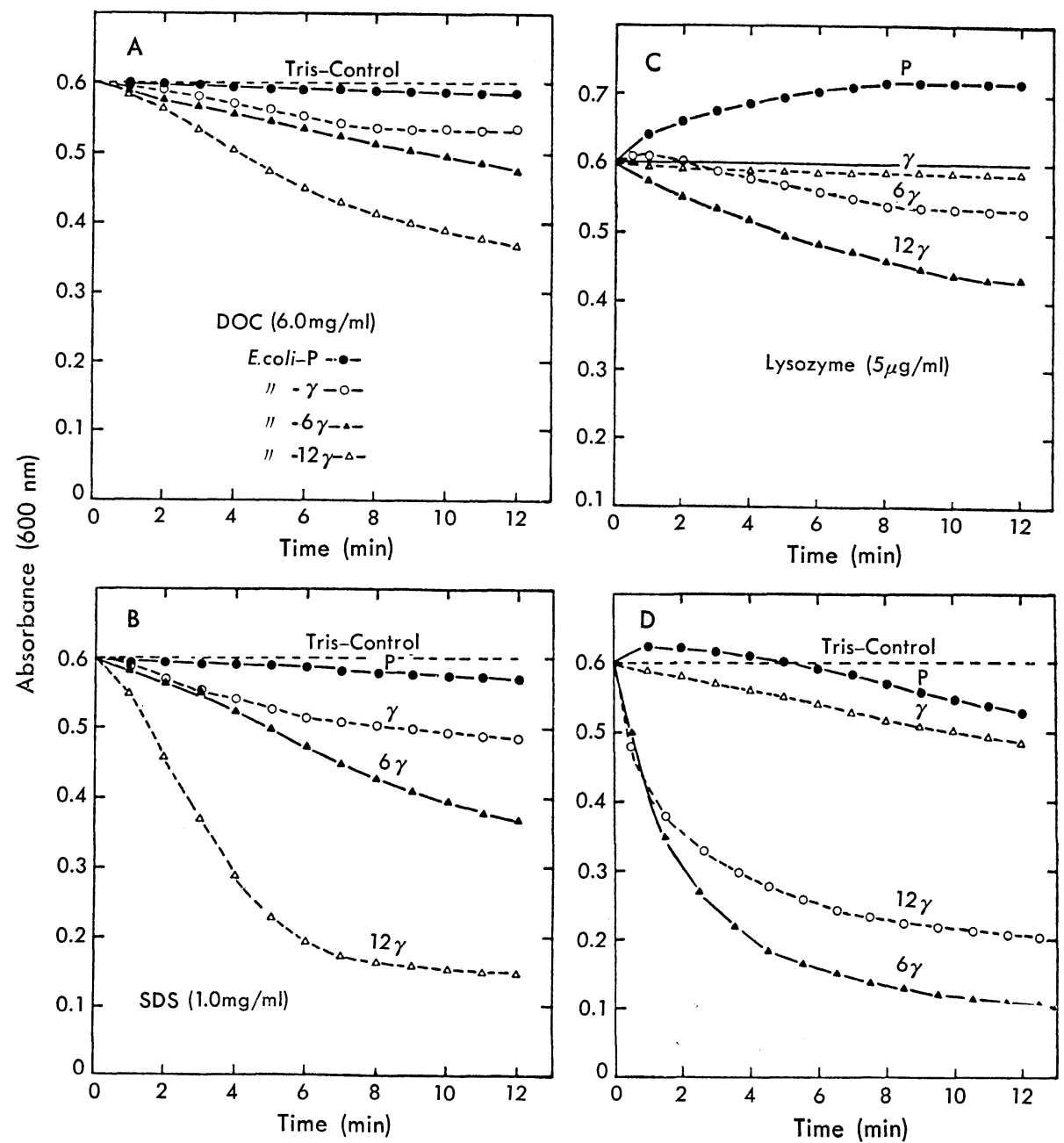

Fig. 4. Time-dependent changes in the turbidity of cell suspensions of wild type E. coli $\mathrm{P}$ and its $\gamma$-irradiation resistant mutant strains $\gamma, 6 \gamma$ and $12 \gamma$, upon treatment with (A) $6 \mathrm{mg} / \mathrm{ml}$ sodium deoxycholate (DOC), (B) $1 \mathrm{mg} / \mathrm{ml}$ sodium dodecyl sulfate (SDS), (C) $5 \mu \mathrm{g} / \mathrm{ml}$ lysozyme, or (D) $10 \mu \mathrm{g} / \mathrm{ml}$ lysozyme plus $5 \times 10^{-5} \mathrm{M}$ EDTA at $25^{\circ}$. 
(d) Effect of EDTA and lysozyme. It has been suggested $(50,53,54)$ that lysozyme sensitivity of Gram-negative bacteria may be an effective means of differentiating cell envelope-defective mutants from the wild-type parent. In order to obtain more information on the nature of the cell surface of $E$. coli $\mathrm{P}$ and its mutant strains, their sensitivity to lysozyme, either alone or in combination with Tris and EDTA, was investigated. Lysozyme treatment alone caused the greatest turbidity decrease in cell suspensions of strain $12 \gamma$. Suspensions of strain $6 \gamma$ showed a slight decrease in turbidity while the strain $\gamma$ cell suspension was unaffected, and suspensions of strain $\mathrm{P}$ increased in optical density (Fig. 4C). The results obtained with strains $6 \gamma$ and $12 \gamma$ are compatible with those reported for Actinomycin-D sensitive mutants of $E$. coli $(50,54)$.

Lysozyme in combination with EDTA $\left(5 \times 10^{-5} \mathrm{M}\right)$ caused a $50 \%$ decrease in optical density in cell suspensions of strains $6 \gamma$ and $12 \gamma$ within 2 min (Fig. 4D). No effect was detected with cell suspensions of strains $P$ and $\gamma$. The optical density decrease after a 12 -min incubation was $84 \%, 75 \%, 18 \%$, and $8 \%$ in strains $6 \gamma$, $12 \gamma, \gamma$, and P, respectively (Fig. 4D). Increasing the concentration of EDTA from $5 \times 10^{-5} \mathrm{M}$ to $5 \times 10^{-4} \mathrm{M}$ caused very little or no lysis of strain $\mathrm{P}$ within a 2 -min period (results not shown). Incubation for $12 \mathrm{~min}$ increased lysis but not to the extent observed with strains $6 \gamma$ and $12 \gamma$ in the presence of $5 \times 10^{-4} \mathrm{M}$ EDTA for $4 \mathrm{~min}$.

\section{Leakage of enzymes}

In previous studies (3-5) we showed that $\gamma$-irradiation resistant mutants of $E$. coli, $6 \gamma$ and $12 \gamma$, leak a periplasmic enzyme, alkaline phosphatase, and a cytoplasmic enzyme, $\beta$-galactosidase. In addition to these enzymes, strains $6 \gamma$ and $12 \gamma$ were also found to leak two other periplasmic enzymes, acid phosphatase and 2,3-cyclic phosphodiesterase. Neither the $\gamma$ nor $\mathrm{P}$ strains leak any enzyme into the growth medium (Table 10).

Table 10. Specific activities of various enzymes and percentage of total activity released into the growth medium during normal growth of wild type $E$. coli $\mathbf{P}$ and its $\gamma$-irradiation resistant mutant strains.

\begin{tabular}{cccccc}
\hline \multirow{2}{*}{$\begin{array}{c}E . \text { coli } \\
\text { strains }\end{array}$} & \multicolumn{5}{c}{$\begin{array}{c}\text { Amount of enzyme present in cells and culture filtrates } \\
\text { (units/ml of culture or culture filtrate) }\end{array}$} \\
\cline { 2 - 6 } & APase & $\begin{array}{c}\text { Acid phos- } \\
\text { phatase }\end{array}$ & $\begin{array}{c}\text { 2,3-Cyclic } \\
\text { phospho- } \\
\text { diesterase }\end{array}$ & $\begin{array}{c}\beta \text {-Galacto- } \\
\text { sidase }\end{array}$ & $\begin{array}{c}\text { NADH } \\
\text { oxidase }\end{array}$ \\
\hline $\mathrm{P}$ & $154(1.5)$ & $34(0)$ & $16(0)$ & $4477(0)$ & $350(0)$ \\
$\gamma$ & $321(1.0)$ & $23(0)$ & $56(0)$ & $4552(0)$ & $352(0)$ \\
$6 \gamma$ & $442(13)$ & $20(2)$ & $42(15)$ & $4697(3)$ & $360(0)$ \\
$12 \gamma$ & $620(29)$ & $20(12)$ & $44(17)$ & $2841(5.5)$ & $358(0)$ \\
\hline
\end{tabular}

Numbers in parentheses represent the \% of total cellular activity released into the culture fluid. APase=alkaline phosphatase. The culture had an optical density of 1.0 at $660 \mathrm{~nm}$, which corresponds to $250 \mu \mathrm{g}$ of protein $/ \mathrm{ml}$. 


\section{DISCUSSION}

The observation that $\gamma$-irradiation resistant mutants $(6 \gamma$ and $12 \gamma)$ of $E$. coli are sensitive to various antibiotics, dyes and detergents suggests that a correlation may exist between sensitivity to antibacterial agents and resistance to $\gamma$-irradiation. Alternatively sensitivity to antibacterial agents may be due to cell envelope alterations rather than radiation resistance. The latter interpretation is consistent with the finding that cell surface-defective mutants obtained by chemical mutagenic agents are also sensitive to various antibiotics, dyes, and detergents $(13,51,54-57)$.

The high sensitivity of the $6 \gamma$ and $12 \gamma$ strains to various antibiotics, detergents, and Methylene Blue appears to be associated with the absence of galactose in their LPS. However, these studies do not eliminate the possibility that other components of the cell envelope may also be involved in the sensitivity of these strains to antibacterial agents, and in the leakage of periplasmic and cytoplasmic enzymes. The tolerance of strain $12 \gamma$ to colicins $\mathrm{H}$ and $\mathrm{K}$, and leakage of $\beta$-galactosidase from cells of $6 \gamma$ and $12 \gamma$, and their sensitivity to DOC and Methylene Blue, all suggest that, in addition to defects in the outer membrane, these strains may have an altered plasma membrane structure. A direct effect of $\gamma$-irradiation on the plasma membrane has been reported for other strains of E. coli (58-61). Evidence for altered membrane permeability in these strains has been obtained from experiments in which formaldehyde was used as a blocking agent. Formaldehyde blocks the entry of substrates such as $o$-nitrophenyl- $\beta$-D-galactoside (ONPG) into cells which have an intact permeability barrier, but it has either very little or no effect on broken or leaky cells $(62,63)$. In contrast to the $\mathrm{P}$ and $\gamma$ strains, the in vivo hydrolysis of ONPG in $6 \gamma$ and $12 \gamma$ was unaffected by formaldehyde $(2,64)$.

From these studies it is concluded that alterations in the cell envelope (cell wall and plasma membrane) are responsible for leakage of enzymes from $\gamma$-irradiation resistant mutants of $E$. coli and for the high sensitivity of these mutant strains to antibacterial compounds.

This research was aided by a grant from the National Research Council (NRC) of Canada. The author was supported by a Bursary from NRC and a Fellowship from McGill University, Montreal. I thank Dr. E. S. Idziak for counsel and encouragement and Dr. Rozanne Poulson for her critical reading of the manuscript.

I am grateful to the following persons for supplying bacterial and phage strains: Drs. B.D. Sanwal, G. Schmidt, O. Luderitz, J. Samarda, S. Silver, and P. Fredericq.

\section{REFERENCES}

1) R. A. Holley, M.Sc. Thesis, McGill University, Montreal, 60 (1969).

2) A. P. Singh and E. S. IdziaK, Proc. Can. Soc. Microbiol., 41 (1970).

3) A. P. Singh, Ph.D. Thesis, McGill University, Montreal, 43-118 (1972).

4) A. P. Singh, R. A. Holley, and E. S. IdziaK, Proc. Can. Soc. Microbiol., 12 (1971).

5) A. P. Singh, K. J. Cheng, J. W. Costerton, E. S. IdziaK, and J. M. Ingram, Can. J. Microbiol., 18, 909 (1972). 
6) H. Artsob, M.Sc. Thesis, McGill University, Montreal (1968).

7) R. D. Pontefract and F. S. Thatcher, Can. J. Microbiol., 11, 271 (1965).

8) R. D. Pontefract and F. S. Thatcher, J. Ultrastruct. Res., 30, 78 (1970).

9) A. P. Singh and E. S. Idziak, Proc. Can. Fed. Biol. Soc., 15, 256 (1972).

10) S. E. Luria, M. J. Adams, and R. C. Ting, Virology, 12, 348 (1960).

11) R. NAGel De ZWAig and S. E. LuRia, J. Bacteriol., 94, 1112 (1967).

12) H. Robern and F. S. Thatcher, Can. J. Microbiol., 14, 711 (1968).

13) S. TAMaki, T. Sato, and M. Matsuhashi, J. Bacteriol., 105, 968 (1971).

14) H. OzeKI, Methods Virol., 4, 565 (1968).

15) R. G. Wilkinson, P. Gemski, and B. A. D. Stocker, J. Gen. Microbiol., 70, 527 (1972).

16) S. F. Sabet and C. A. Schnattman, J. Bacteriol., 108, 422 (1971).

17) O. WestPhaL and K. JANn, Methods Carbohyd. Chem., 5, 83 (1965).

18) M. J. Osborn, Proc. Natl. Acad. Sci. U.S., 50, 499 (1963).

19) P. S. Chen, T. Y. Toribara, and M. Warner, Anal. Chem., 28, 1756 (1956).

20) M. R. Heinrich and S. M. Howard, Methods Enzymol., 9, 407 (1966).

21) S. Saito. M. Ozutsumi, and K. Kurahashi, J. Biol. Chem., 242, 2362 (1967).

22) D. B. WiLson and D. S. Hogness, Methods Enzymol., 8, 229 (1966).

23) R. W. Brockman and L. A. HepPeL, Biochemistry, 7, 2554 (1968).

24) A. Torriani, Biochim. Biophys. Acta, 38, 460 (1960).

25) J. Lederberg, J. Bacteriol., 60, 381 (1950).

26) M. H. Malamy and B. L. HoReCKer. Biochemistry, 3, 1889 (1964).

27) O. Luderitz, A. M. Staub, and O. WestPhal, Bacteriol. Rev., 30. 192 (1966).

28) A. A. LindBerg, Ann. Rev. Microbiol., 27, 205 (1973).

29) H. NiKaIDo, Bacterial Membranes and Walls, Microbiol. Ser., 1, 131 (1974).

30) J. J. Licciardello, J. T. R. Nickerson, S. A. Goldblith, C. A. Shannon, and S. A. Bishop, Appl. Microbiol., 18, 24 (1969).

31) N. A. Epps and E. S. IDZIaK, Appl. Microbiol., 19, 338 (1970).

32) J. E. L. Corry and T. A. Roberts, J. Appl. Bacteriol., 33, 733 (1970).

33) R. Davies and J. SinsKeY, J. Bacteriol., 113, 133 (1973).

34) M. A. Jesattis and W. F. Goebel, J. Exp. Med., 96, 409 (1952).

35) W. WeIDEL, Ann. Rev. Microbiol., 12, 27 (1958).

36) P. FredericQ, J. Gen. Microbiol., 18, 527 (1958).

37) K. KURAHASHI and A. J. WaHBa, Biochim. Biophys. Acta, 30, 298 (1958).

38) M. B. Yarmolinsky, H. Wiesmeyer, H. M. KalCKar, and E. Jordan, Proc. Natl. Acad. Sci. U.S., 45, 1786 (1959).

39) A. D. Elbein and E. C. Heath, J. Biol. Chem., 240, 1919 (1965).

40) D. Rosenberg and A. S. Keston, Arch. Biochem. Biophys., 120, 239 (1967).

41) S. SCHLECHT and O. WeSTPHAL, Naturwissenschaften, 10, 494 (1968).

42) S. SchleCht and O. WestPhal, Zentralbl. Bakteriol. Parasitenkd. Infektionskr. Hyg. Abt. Orig. A, 213, 365 (1970).

43) G. Schmidt, S. Schlecht, O. Luderitz, and O.WestPhal, Zentralbl. Bakteriol. Parasitenkd. Infektionskr. Hyg. Abt. Orig. A, 209, 483 (1969).

$44)$ R. J. Roantree, T. Kuo, D. G. Macphee, and B. A. D. Stocker, Bacteriol. Proc., 79 (1969).

45) S. SchleCht and G. SсHмidt, Zentralbl. Bakteriol. Parasitenkd. Infektionskr. Hyg. Abt. Orig. A, 213, 356 (1970).

46) S. SchleCht and G. SсHмidt, Zentralbl. Bakteriol. Parasitenkd. Infektionskr. Hyg. Abt. Orig. A, 212, 505 (1969).

47) K. E. Sanderson, T. Macalister, J. W. Costerton, and K. J. Cheng, Can. J. Microbiol., 20, 1135 (1974).

48) M. R. J. SAlton and A. Tomasz, Ann. N.Y. Acad. Sci., 235, 1 (1974). 
49) I. B. Holland, E. J. Threlfall, E. M, Holland, V. Darby, and A. C. R. Samson, J. Gen. Microbiol., 62, 371 (1970).

50) C. S. Buller and K. DobBs, Biochem. Biophys. Res. Commun., 43, 568 (1971).

51) H. L. ENNIS, J. Bacteriol., 107, 486 (1971).

52) E. N. WhITNEY, Genetics, 67, 39 (1971).

53) G. Weinbaum, J. Gen. Microbiol., 42, 83 (1966).

54) M. Sekiguchi, and S. IidA, Proc. Natl. Acad. Sci. U.S., 58, 2315 (1967).

55) A. Higa and M. Mandel, Mol. Gen. Genet., 108, 41 (1970).

56) S. NORMARK, Genet. Res., 16, 63 (1970).

57) S. Normark, H. G. Boman, and G.D. Bloom, Acta Pathol. Microbiol. Scand., 79, 651 (1971).

58) D. Billen, Arch. Biochem. Biophys., 67, 333 (1957).

59) E. E. Woodside and W. Kocholaty, J. Bacteriol., 87, 1140 (1964).

60) E. C. Pollard and P. K. Weller, Radiat. Res., 35, 722 (1968).

61) M. B. Yatvin, P. G. Wood, and S. M. Brown, Biochim. Biophys. Acta, 287, 390 (1972).

62) A. L. Косн Biochim. Biophys. Acta, 79, 177 (1964).

63) G. A. Scarborough, Rumley, and E. P. Kennedy, Proc. Natl. Acad. Sci. U.S., 60, 951 (1968).

64) A. P. Singh and E. S. IdzIAK, Proc. Can. Soc. Microbiol., 42 (1970).

65) H. L. EnNis and M. I. Bloomstein, Ann. N.Y. Acad. Sci., 235, 593 (1974).

66) A. L. TAYLoR and C. D. TROTter, Bacteriol. Rev., 36, 504 (1972). 